\title{
PROFIL TUMOR NECROSIS FACTOR (TNF- $\alpha$ ) BERDASARKAN INDEKS MASSA TUBUH (IMT) PADA MAHASISWA FAKULTAS KEDOKTERAN UNSRAT ANGKATAN 2014
}

\author{
${ }^{1}$ Ivander A. Supit \\ ${ }^{2}$ Damajanty H. C. Pangemanan \\ ${ }^{2}$ Sylvia R. Marunduh
}

\author{
${ }^{1}$ Kandidat Skripsi Fakultas Kedokteran Universitas Sam Ratulangi Manado \\ ${ }^{2}$ Bagian Fisiologi Fakultas Kedokteran Universitas Sam Ratulangi Manado \\ Email: iasupit_11_298@yahoo.com
}

\begin{abstract}
Tumor Necrosis Factor alpha (TNF- $\alpha$ ) is one of the pleiotrophic cytokines that plays a role in the inflammatory process, initiates and activates polymorphonuclears (PMNs), therefore the PMNs can reach the infection site. This study aimed to determine the profile of TNF- $\alpha$ based on body mass index (BMI) among the students of the Faculty of Medicine Unsrat batch 2014. This was a survey study with a cross sectional design. The study population was students of the Faculty of Medicine University of Sam Ratulangi Manado batch 2014. The results showed that samples with BMI 18-18.9 had an average TNF- $\alpha$ level of $69.48 \mathrm{pg} / \mathrm{ml}$; samples with BMI 19-19.9 had an average TNF- $\alpha$ level of $78.04 \mathrm{pg} / \mathrm{ml}$; samples with BMI 20-20.9 had an average TNF- $\alpha$ level of $61.94 \mathrm{pg} / \mathrm{ml}$; samples with BMI 21-21.9 had an average TNF- $\alpha$ level of $64.37 \mathrm{pg} / \mathrm{ml}$; and samples with BMI 22-22.9 had the highest average level of TNF- $\alpha$ which was $78.65 \mathrm{pg} / \mathrm{ml}$. Conclusion: In this study, all students with normal body mass index (BMI) had normal levels of TNF- $\alpha$, which was 10-100 pg/ml.
\end{abstract}

Keywords: TNF- $\alpha$, immune system, body mass index (BMI)

\begin{abstract}
Abstrak: Tumor necrosis factor alpha (TNF- $\alpha$ ) adalah salah satu sitokin pleiotropik yang berperan dalam proses inflamsi, menginisiasi polymorphonuclear (PMN) dan mengaktivasinya sehingga PMN dapat mencapai tempat infeksi. Penelitian ini bertujuan untuk mengetahui profil TNF- $\alpha$ berdasarkan indeks massa tubuh (IMT) pada mahasiswa Fakultas Kedokteran Unsrat angkatan 2014. Jenis penelitian bersifat survei dengan rancangan potong lintang. Populasi penelitian ialah mahasiswa Fakultas Kedokteran Unsrat angkatan 2014. Hasil penelitian memperlihatkan bahwa sampel dengan IMT 18-18,9 memiliki nilai rerata kadar TNF- $\alpha$ 69,48 pg/ml; sampel dengan IMT 19-19,9 memilki nilai rerata kadar TNF- $\alpha$ 78,04 $\mathrm{pg} / \mathrm{ml}$; sampel dengan IMT 20-20,9 memiliki nilai rerata kadar TNF- $\alpha$ 61,94 pg/ml; sampel dengan IMT 21-21,9 memiliki nilai rerata kadar TNF- $\alpha 64,37$ pg/ml; dan sampel dengan IMT 22-22,9 memiliki nilai rerata TNF- $\alpha$ tertinggi yaitu 78,65 pg/ml. Simpulan: Pada penelitian ini, semua mahasiswa Fakultas Kedokteran Unsrat angkatan 2014 dengan IMT normal memiliki kadar TNF- $\alpha$ normal, yaitu $10-100 \mathrm{ml} / \mathrm{pg}$.
\end{abstract}

Kata kunci: TNF- $\alpha$, sistem imun, indeks massa tubuh (IMT)

Tumor necrosis factor alpha (TNF- $\alpha)$ merupakan sitokin utama pada respon inflamasi akut terhadap bakteri Gramnegatif dan mikroba lainnya. Infeksi yang berat dapat memicu produksi TNF dalam jumlah besar yang menimbulkan reaksi sistemik. TNF disebut TNF- $\alpha$ atas dasar historis dan untuk membedakannya dari 
TNF- $\beta$ atau limfotoksin. Sumber utama TNF- $\alpha$ ialah fagosit mononuklear dan sel T yang diaktifkan antigen, sel NK, dan sel mast. Lipopolisakarida merupakan rangsangan poten terhadap makrofag untuk menyekresi TNF. IFN- $\gamma$ yang diproduksi sel $\mathrm{T}$ dan sel NK juga merangsang makrofag antara lain meningkatkan sintesis TNF. ${ }^{1}$

TNF- $\alpha$ mempunyai beberapa fungsi dalam proses inflamasi, yaitu dapat meningkatkan peran pro trombotik dan merangsang molekul adhesi dari sel leukosit serta menginduksi sel endotel, berperan dalam mengatur aktivitas makrofag dan respon imun dalam jaringan dengan merangsang faktor pertumbuhan dan sitokin lain, berfungsi sebagai regulator dari hematopoetik serta komitogen untuk sel $\mathrm{T}$ dan sel B serta aktivitas sel neutrofil dan makrofag. TNF- $\alpha$ juga memiliki fungsi tambahan yang menguntungkan termasuk peranannya dalam respon imun terhadap bakteri, virus, jamur, dan invasi parasit. ${ }^{2,3}$

Hampir semua proses inflamasi mengakibatkan aktivasi makrofag jaringan dan infiltrasi monosit darah. Aktivasi ini menyebabkan banyak perubahan dalam sel, di antaranya ialah produksi TNF, IL-1, dan IL-6, yaitu sitokin-sitokin yang meyebabkan efek multipel pada hospes. Efek-efek ini meliputi: 1) induksi demam; 2) respon fase akut hepatik yang disertai lekositosis dan produksi protein fase akut seperti CReactive Protein (CRP); dan 3) diferensiasi atau aktivasi dari sel $T$, sel $B$ dan makrofag. ${ }^{4}$

Beberapa laporan menyatakan efek TNF- $\alpha$ pada obesitas berkaitan dengan resistensi insulin, peningkatan asam lemak bebas oleh adiposit, penurunan sintesis adiponektin, dan gangguan sinyal insulin. Mekanisme molokuler yang bertanggung jawab terhadap penurunan peran insulin, terutama pada individu obes, ialah bahwa TNF- $\alpha$ yang menyebabkan fosforilasi serin dari insulin receptor-substrate (IRS-1) dalam adiposit dan hepatosit yang dikultur, sebaliknya TNF- $\alpha$ menghambat fosforilasi tirosin dan aktivitas reseptor insulin IRS-1.
Indeks massa tubuh merupakan sebuah pengukuran dalam statistik yang membandingkan berat badan dan tinggi badan seseorang. Walaupun hal ini tidak sebenarnya mengukur persentasi lemak tubuh, tetapi indeks masa tubuh merupakan alat yang berguna untuk mengestimasi berat badan yang sehat berdasarkan tinggi orang tersebut. Karena pengukuran dan penghitungan yang mudah, indeks ini banyak digunakan secara luas sebagai alat diagnostik untuk mengidentifikasi masalah berat badan dalam populasi, biasanya untuk individu yang kurus (di bawah normal), kelebihan berat badan dan obesitas. Indeks massa tubuh didefinisikan sebagai berat badan seseorang dibagi dengan tinggi badannya pangkat kuadrat. $^{6}$

\section{METODE PENELITIAN}

Penelitian bersifat survei dengan rancangan potong lintang. Penelitian ini dilaksanakan di aula Fakultas Kedokteran Universitas Sam Ratulangi Manado antara bulan Oktober-Desember 2014. Populasi penelitian ialah mahasiswa Fakultas Kedokteran Unsrat angkatan 2014.

Sampel penelitian merupakan bagian dari populasi yang memenuhi kriteria inklusi, yaitu: wanita umur 16-19 tahun, memiliki nilai IMT dalam batas normal yaitu 18,5-22,9, bersedia menjadi responden, sehat saat diperiksa, tidak mengonsumsi obat- obatan anti inflamasi dan menandatangani informed consent. Pengukuran kadar TNF- $\alpha$ menggunakan teknik Sandwich ELISA dengan menggunakan kit Quantikine ELISA Human TNF- $\alpha$, R\&D, USA.

\section{HASIL PENELITIAN}

Tabel 1. Distribusi Sampel Berdasarkan Kelompok Umur

\begin{tabular}{cccc}
\hline $\begin{array}{c}\text { Umur } \\
\text { (Tahun) }\end{array}$ & $\mathrm{n}$ & $\%$ & $\begin{array}{c}\text { Rerata TNF- } \alpha \\
(\mathrm{pg} / \mathrm{ml})\end{array}$ \\
\hline $16-17$ & 12 & 44,4 & 60,30 \\
$18-19$ & 15 & 55,6 & 67,5 \\
TOTAL & 27 & 100 & \\
\hline
\end{tabular}


Tabel 2. Distribusi Sampel Berdasarkan Berat Badan

\begin{tabular}{ccc}
\hline $\begin{array}{c}\text { Berat Badan } \\
(\mathrm{kg})\end{array}$ & $\mathrm{n}$ & $\begin{array}{c}\text { Rerata TNF- } \alpha \\
(\mathrm{pg} / \mathrm{ml})\end{array}$ \\
\hline $41-45$ & 4 & 79,13 \\
$46-50$ & 9 & 62,96 \\
$51-55$ & 8 & 63,52 \\
$56-60$ & 5 & 73,92 \\
$\geq 61$ & 1 & 70,49 \\
\hline TOTAL & 27 & \\
\hline
\end{tabular}

Tabel 3. Distribusi Sampel Berdasarkan Tinggi Badan

\begin{tabular}{cccc}
\hline $\begin{array}{c}\text { Tinggi } \\
\text { Badan }(\mathrm{cm})\end{array}$ & $\mathrm{n}$ & $\%$ & $\begin{array}{c}\text { Rerata TNF- } \alpha \\
(\mathrm{pg} / \mathrm{ml})\end{array}$ \\
\hline $146-150$ & 3 & 11,11 & 84,93 \\
$151-155$ & 7 & 25,93 & 64,24 \\
$156-160$ & 9 & 33,33 & 64,37 \\
$161-165$ & 6 & 22,22 & 68,03 \\
$\geq 166$ & 2 & 7,41 & 73,7 \\
TOTAL & 27 & 100 & \\
\hline
\end{tabular}

Tabel 4. Distribusi Sampel Berdasarkan Indeks Masa Tubuh (IMT)

\begin{tabular}{cccc}
\hline IMT & $\mathrm{n}$ & $\%$ & $\begin{array}{c}\text { Rerata TNF- } \alpha \\
(\mathrm{pg} / \mathrm{ml})\end{array}$ \\
\hline $18-18,9$ & 3 & 11,11 & 69,48 \\
$19-19,9$ & 4 & 14,82 & 78,04 \\
$20-20,9$ & 8 & 29,63 & 61,94 \\
$21-21,9$ & 9 & 33,33 & 64,37 \\
$22-22,9$ & 3 & 11,11 & 78,65 \\
TOTAL & 27 & 100 & \\
\hline
\end{tabular}

\section{BAHASAN}

Pada penelitian ini, sampel yang berumur 16-17 tahun memiliki rerata kadar TNF- $\alpha \quad 60,30 \mathrm{pg} / \mathrm{ml}$ dan sampel yang berumur 18-19 tahun memiliki rerata kadar TNF- $\alpha$ 67,5 pg/ml (Tabel 1). Meningkatnya TNF- $\alpha$ dapat disebabkan oleh faktor umur. Berdasarkan penelitian yang dilakukan oleh Gupta S et al, ${ }^{7}$ terjadi peningkatan kadar TNF- $\alpha$ pada proses penuaan. Hal ini disebabkan karena terjadi peningkatan sinyal apoptosis dan menurunnya sinyal kelangsungan hidup. Pada penelitian ini kadar TNF- $\alpha$ masih dalam batas normal, karena melihat umur dari sampel yang tergolong masih usia muda.
Sistem imun berpengaruh terhadap tinggi dan rendahnya kadar TNF- $\alpha$. Ketika sistem imun menurun maka tubuh akan lebih mudah terserang penyakit. Hal itu dikarenakan kemampuan imunitas tubuh yang lemah untuk melawan infeksi sehingga menyebabkan TNF- $\alpha$ diproduksi secara berlebihan dan kadar TNF- $\alpha$ meningkat. Faktor usia memengaruhi kuat atau lemahnya sistem imun. Pada orang yang sudah memasuki usia tua, kecepatan respon imun mulai menurun, sehingga lebih mudah terserang penyakit dan menyebabkan kadar TNF- $\alpha$ meningkat. ${ }^{8}$ Pada penelitian ini usia dari sampel masih termasuk dalam usia muda, sehingga masih memiliki respon imun yang baik dan kadar TNF- $\alpha$ yang normal.

Pada usia muda kadar hormon khususnya growth hormone berada dalam kondisi optimal. Fungsi growth hormone dapat menekan tingginya kadar TNF- $\alpha$. Hal tersebut memberikan dampak yang baik bagi kadar TNF- $\alpha$ di usia muda. ${ }^{9}$ Pada penelitian ini dapat dilihat kadar TNF- $\alpha$ pada sampel memiliki rerata nilai yang normal (Tabel 1).

Pada Tabel 5 dapat dilihat sampel yang memiliki IMT 21-22,9 memiliki rerata kadar TNF- $\alpha$ tertinggi yaitu 78,65 pg/ml. Nilai IMT sampel dalam batas normal sehingga kadar TNF- $\alpha$ masih normal. Hal ini akan berbeda jika nilai IMT di atas normal atau obesitas, diperkirakan kadar TNF- $\alpha$ bisa di atas nilai normal yang disebakan karena peningkatan sekresi TNF$\alpha$ oleh jaringan adiposa. Jaringan adiposa merupakan organ endokrin dinamik yang menyekresikan adipokin yang berkontribusi pada inflamasi sistemik dan vaskular, salah satunya ialah TNF- $\alpha .^{10,11}$

Faktor lain yang memengaruhi kadar TNF- $\alpha$ ialah stres. Saat terjadi stres maka hormon glukokortikoid dan kortisol memicu reaksi anti-inflamasi sistem imun yang menyebabkan peningkatan kadar TNF- $\alpha{ }^{8}$

\section{SIMPULAN}

Dari hasil penelitian dapat disimpulkan bahwa semua mahasiswa Fakultas 
Kedokteran Unsrat angkatan 2014 dengan IMT normal memiliki kadar TNF- $\alpha$ normal, yaitu $10-100 \mathrm{ml} / \mathrm{pg}$.

\section{DAFTAR PUSTAKA}

1. Baratawidjaya KG, Rengganis I. Imunologi Dasar (Edisi ke 9). Jakarta: FKUI, 2010; p. 226.

2. Soeroso A. Sitokin. Oftalmologi Indonesia. 2007;5:171-80.

3. Yani L, Ilhamjaya P, Gatot SL, Wijaya A, Suryani A. Korelasi antara adiponektin dengan Tumor Necrosis Factor Alpha (TNF-a) pada pria Indonesia obes nondiabetes. MKI. 2011:6;1.

4. Ishartadiati K. Peranan TNF, IL-1, dan IL6 pada respon imun terhadap protozoa. Surabaya: FK Universitas Wijaya Kusuma.

5. Setiawan M. Peran resistensi insulin, adiponektin, dan inflamasi pada kejadian dislepidemia aterogenik. 2012.

6. Body Mass Index. Available from: www.idp-europe.org
7. Gupta S, Chiplunkar S, Kim C, Yel L, Gollapudi S. Effect of age on molecular signaling of TNF-alphainduced apoptosis in human lymphocytes. Pubmed. 2003; 124(4):503-9.

8. Fatmah. Respons imunitas yang rendah pada tubuh manusia usia lanjut. Makara Kesehatan. 2006;10(1): 47-53.

9. Misitahari MI. Pemberian growth hormone menurunkan kadar tumor necrosis factor- $\alpha$ (tnf- $\alpha$ ) pada tikus jantan yang dislipidemia [Tesis]. 2011.

10. Laurence H, Karima B, Philippe R, Ravi M, Palaniyandi R, Frank $T$, et al. Signaling pathways involved in LPS induced TNFalpha production in human adipocytes. Journal of Inflammation. 2010;7:1.

11. Mukhtar D. Makrofag pada jaringan adiposa obes sebagai penanda terjadinya resistensi insulin. Widya. 2012;28(317):29-33. 